Електронне наукове фахове видання "Ефективна економіка" включено до переліку наукових фахових видань України з питань економіки

(Категорія «Б», Наказ Міністерства освіти і науки України від 11.07.2019 № 975) www. economy.nayka.com.ua | № 5, 2020| 28.05.2020 p.

DOI: $10.32702 / 2307-2105-2020.5 .1$

УДК 338.1

Yu. Safonov

Doctor of Economic Sciences, Professor,

Kyiv National Economic University named after Vadym Hetman

ORCID ID: 0000-0001-5623-1965

V. Borshch

PhD in Economics, Associate Professor,

Odessa national I. I. Mechnikov University

ORCID ID: 0000-0001-9106-9078

\title{
ECONOMIC CONSEQUENCES OF COVID-19 AND THE CONCEPTS OF THEIR OVERCOMING
}

\author{
Ю. М. Сафонов, \\ д. е. н., профресор, \\ ДВНЗ «Київський національний економічний університет імені Вадима Гетьмана» \\ B. I. Борш, \\ к. е. н., доиент, \\ Одеський наџіональний університет імені I. I. Мечникова
}

\section{ЕКОНОМІЧНІ НАСЛІДКИ СОVID-19 ТА КОНЦЕПТИ ПОДОЛАННЯ}

The main aim of this paper is to analyze the economic impact of COVID-19 pandemic on the global economy. Methods of summarization, formal logic and analytical methods were used in the research. The informational database is the official web-sites of the international organizations such as World Health Organization, International Labor Organization, and United Nations Development Program.

In the paper the economic consequences of COVID-19 and the concepts of their overcoming are examined. The authors analyze the main problems, caused by COVID-pandemic worldwide, among which the following are determined: (1) decrease of employment level; (2) high risk of work closures by economic branches; (3) global working hours reduction by regions; (4) potential impacts of the pandemic on earnings of informal workers.

The authors highlight that consequences of the current crisis are estimated 3-4 times more than the financial crisis of 2008. It was mentioned that the COVID-19 pandemic has a significant impact on the markets' development by creating the great disproportion in the markets' development. Also, in the paper the impacts of recommended and required workplace closures and the employment in countries with recommended or required workplace are presented. Impact of the COVID-19 crisis on enterprises (employers and own-account workers) in risky sectors by the economic sectors is given. The potential consequences are illustrated by the example of the economy of the G7 countries and EU. Annual output gap for EU countries was presented in the research.

Three scenarios for the development of the COVID-19 pandemic were examined. They depend on termination of the economy's lockdown. 
In the paper the necessity of the risk assessment scales and established crisis monitoring processes and systems have been proved. The example of the risk assessment scale, proposed by Schlumberger, was illustrated.

Road map for the minimization of losses from COVID-19 was proposed by the authors, which takes into account the main problems identified by WHO as prerequisites. The COVID-19 crisis program, drawn up by authors, was presented in the paper.

Основною метою даного дослідження є аналіз економічного впливу пандемї COVID-19 на світову економіку. У дослідженні використовувались методи узагальнення, формальної логіки та аналітичний метод. Інформачійною базою даних слугували офіційні веб-сайти таких міжнародних організачій, як Всесвітня організація охорони здоров'я, Міжнародна організація прачі та Програма розвитку ОOH.

У статті досліджені економічні наслідки пандемї COVID-19 на світову економіку та сформовані конщепти їх подолання. Авторами були досліджені основні проблеми, що були спричинені COVID-19, а саме (1) зниження рівня зайнятості; (2) ризики зриву діяльності за основними ризиковими галузями; (2) зменшення рівня годин роботи за галузями економіки; (4) безпосередній вплив пандемії на неофіиійно зайняте населення у всьому світі.

Авторами було зазначено, щцо негативні економічні та фінансові наслідки від кризи, спричиненої пандемією COVID-19, в 3-4 рази вищі, ніж від фінансової кризи 2008 року. Потенційні наслідки за галузями проілюстровані на прикладі країн G7 та СC.

Було проаналізовано три основні сиенарії розвитку пандемії, які залежать від тривалості карантинних заходів. Також було відзначено, шзо пандемія COVID-19 має значний вплив на розвиток ринків, створюючи велику диспропориію в розвитку ринків. Також у статті наведено вилив від рекомендованого та необхідного закриття робочих місиь на працевлаштування в країнах. Проаналізовано вплив економічної кризи від COVID-19 на підприємства (роботодавців та самозайняте населення) у ризикових секторах за секторами економіки. Потенційні наслідки проілюстровані на прикладі економіки країн G7 та ЄC. Щорічний розрив у виробнищтві для країн СС був представлений у дослідженні.

Було розглянуто три сценарії розвитку пандемії COVID-19. Вони залежать від припинення відключення економіки.

Акцентується увага на запровадженні національних шкал очінки ризиків від COVID-19. Приклад оиінки ризиків проілюстровано на прикладі шкали, запропонованої компанією Schlumberger. Запропоновані заходи шеодо мінімізаиї негативних наслідків від COVID-19 та програму дій для урядів краӥн.

Keywords: COVID-19 pandemic; economic consequences; economic impact; employment; informal workers; economic branches; healthcare market; annual output gap; crisis management; crisis program for COVID-19.

Ключові слова: пандемія COVID-19; економічні наслідки; економічний вплив; зайнятість; неформальні прачівники; галузі економіки; ринок охорони здоров'я; щцорічний розрив у виробництві; кризис-менеджмент; програма подолання негативних наслідків від COVID-19.

\section{practical tasks}

Formulation of the problem in generally and related issues, which are important in scientific and

Nowadays, there is ongoing discussion about the readiness of Governments and national health care systems to the COVID-19 pandemic and also in general about the level of the national health cares' efficiency. This discussion is caused by the COVID-19 pandemic (2019-2020). It was first identified in December, 2019, in Wuhan (Chine), and it was defined as pandemic on 11th of March, 2020.

It became apparent that the most national health systems worldwide have been unable to respond quickly and efficiently to the emergence of the SARS-CoV-2 virus, even those identified in the ranking of countries as leaders in terms of health efficiency and safety. The emergence of a new virus has exposed a number of problems in most national health care systems, i.e.: 
1) the inability to respond quickly to exceptional force majeure on a large scale;

2) low "throughput" of health care facilities;

3) low level of flexibility in decision-making process (large-scale quarantine and lock-down, testing, rapid change of treatment guidelines, etc.);

4) the shortage of medical equipment and medical supplies needed to sustain patients' lives and the absence of pharmaceuticals to overcome the spread of SARS-CoV-2;

5) shortage of the qualified medical staff (doctors, nursing staff, laboratory workers so on);

6) lack of mechanisms for solving the problem of psychological and physical load on medical staff.

The list of these problems is not exhaustive and differs from the country's level of economic and social development, the mentality and cultural characteristics existing in the countries, etc. However, it can be safely stated that most national healthcare systems (with some exceptions where urgent measures have been taken, and therefore there is no high incidence and mortality rate of COVID-19 among the population), were not prepared to spread of the disease globally.

Today, the key issue is the effectiveness of government decisions and COVID-19's coping strategies. The coronavirus pandemic has long-lasting effects, in addition to its own spread of disease and quarantine measures, which have already significantly impacted the economy of the most countries.

Thus, by April 30, 2020, according to WHO, there are more than 3 million confirmed cases of COVID-19 (more than 988 thousand cases were registered among EU countries), including 211,000 confirmed deaths (over 105,000 in EU countries) worldwide [2]. WHO estimates that the worldwide COVID-19 mortality rate is $3.4 \%$ (by March 3, 2020), compared to an annual influenza mortality rate, which is below $1 \%$ [12].

As the SARS-CoV-2 virus has spread around the world, concerns have shifted from health care's provision to the issues of overcoming the crisis due to the temporary complete or partial termination of business activity in many countries [11]. These measures directly affect the level of business activity in specific industries.

Analysis of the recent studies and publications that have initiated the solution of this problem, definition of the unresearched part of the paper's general problem

Economic impact of COVID-19 has not been researched among Ukrainian scientists, in contrast to Russian, among which we can highlight the following ones: Bobylev S. [1], Mazneva D. [9] and so on. Among the foreign authors we can note such as Helge Sigurd Næss-Schmidt, Jonas Bjarke Jensen, Benjamin Barner Christiansen, Laura Virtanen, Astrid Leth Nielsen [6; 7] and so on, who has analyzed COVID-19 Exit strategies in the case of Scandinavian countries and researched the economic consequences of the COVID-19 pandemic.

\section{The formulation of the paper's objective}

Consequently, the main goal of this research is to analyze the economic consequences of COVID-19 pandemic on the global economy.

Presentation of the basic material of the study with justification of the obtained scientific results

Today, the economic impact of COVID-19 far outweighs the direct impact of the pandemic, namely:

1) increasing unemployment in many countries around the world and reducing wages, which, consequently, reduces the purchasing power of the population and therefore the demand; households;

2) a high level of uncertainty, leading to the shutdown of investment activity both from business and

3) the reduction of economic entities' production capacity, leading to an increase in the bankruptcy level.

Thus, according to International Labor Organization (ILO), the COVID-19 pandemic has had a significant impact on labor markets worldwide. As of April 30, 2020, according to ILO estimations:

1. The ratio of workers, residing in countries with recommended or required work closures, is $68 \%$ (although this rate had fallen comparing with similar estimation as of April 22, 2020, which was about 81\%) (Fig. 1.). 


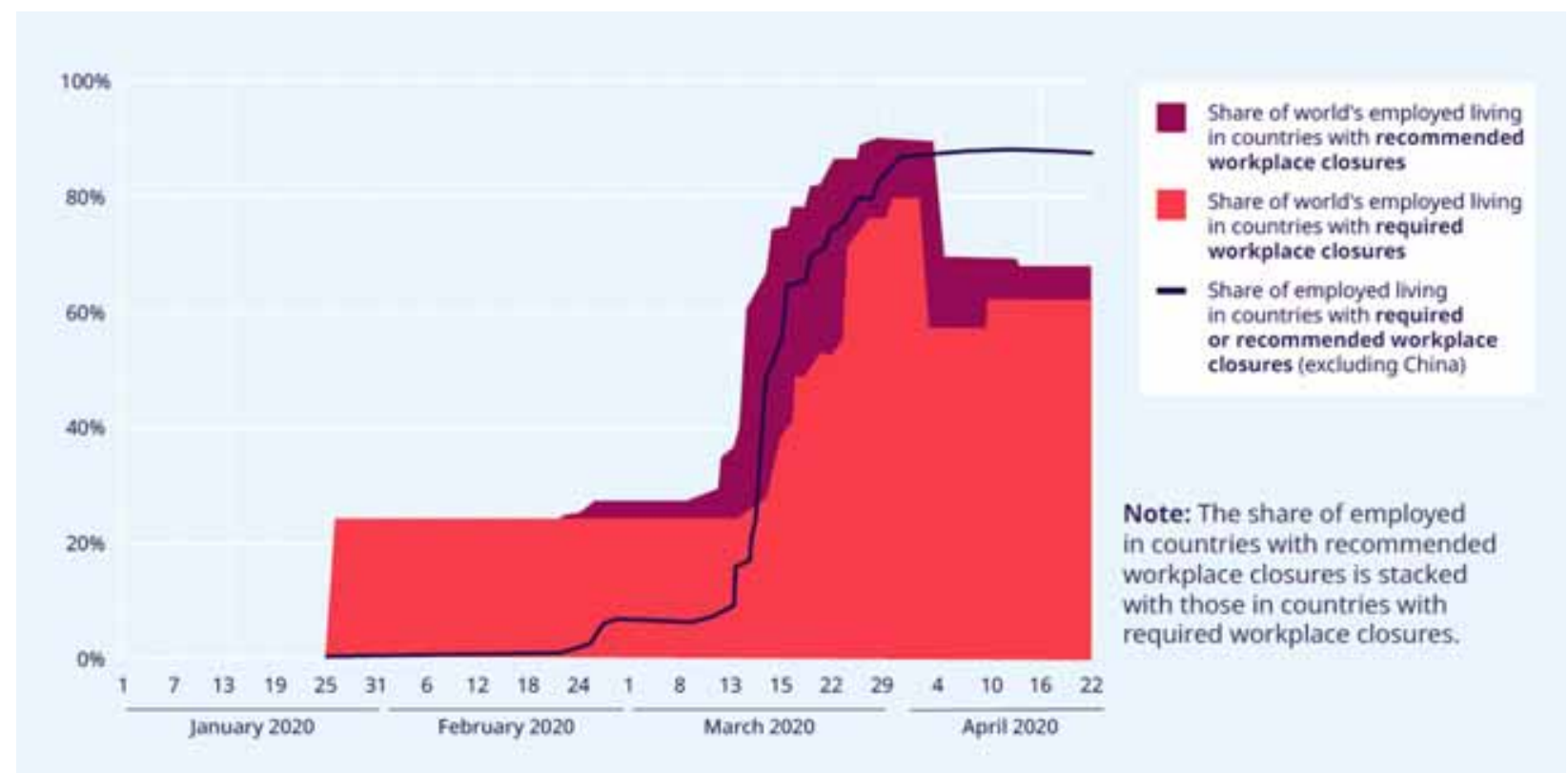

Fig. 1. Impacts of recommended and required workplace closures (as of April 22, 2020). Employment in countries with recommended or required workplace closures

(Source: $[11, p .3]$ )

2. $31.5 \%$ of the world's population is employed in risky sectors: the sectors with a high risk of work closures, among which are hotel and restaurant business, retail trade, manufacturing, real estate operations, business and administrative activities. Impact by economic sectors is presented in Table. 1.

Table 1.

Impact of the COVID-19 crisis on enterprises (employers and own-account workers) in risky sectors

\begin{tabular}{|c|c|c|c|c|c|c|}
\hline \multirow[b]{2}{*}{ Economic sector } & \multirow[b]{2}{*}{$\begin{array}{l}\text { Impact of } \\
\text { crisis on } \\
\text { economic } \\
\text { output }\end{array}$} & \multicolumn{5}{|c|}{ Baseline employment situation (global estimates for 2020 prior to COVID-19) } \\
\hline & & $\begin{array}{c}\text { Employers } \\
\text { (millions) }\end{array}$ & $\begin{array}{c}\text { Own- } \\
\text { account } \\
\text { workers } \\
\text { (millions }\end{array}$ & $\begin{array}{c}\text { Share of } \\
\text { own-account } \\
\text { workers in } \\
\text { total } \\
\text { employment } \\
(\%)\end{array}$ & $\begin{array}{c}\text { Share of } \\
\text { employed } \\
\text { in firms with } \\
\text { 2-9 employees } \\
\text { in total } \\
\text { employment } \\
(\%)\end{array}$ & $\begin{array}{c}\text { Share of } \\
\text { employed } \\
\text { in firms with } \\
10+\text { employees } \\
\text { in total } \\
\text { employment } \\
(\%)\end{array}$ \\
\hline $\begin{array}{l}\text { Wholesale and } \\
\text { retail trade; } \\
\text { repair of motor } \\
\text { vehicles and } \\
\text { motorcycles }\end{array}$ & High & 21 & 211 & 45 & 25 & 30 \\
\hline Manufacturing & High & 12 & 99 & 19 & 15 & 66 \\
\hline $\begin{array}{l}\text { Accommodation } \\
\text { and food services }\end{array}$ & High & 7 & 44 & 29 & 29 & 41 \\
\hline $\begin{array}{l}\text { Real estate; } \\
\text { business and } \\
\text { administrative } \\
\text { activities }\end{array}$ & High & 7 & 35 & 21 & 23 & 56 \\
\hline $\begin{array}{l}\text { Arts, } \\
\text { entertainment and } \\
\text { recreation, and } \\
\text { other services }\end{array}$ & $\begin{array}{l}\text { Medium- } \\
\text { high }\end{array}$ & 4 & 57 & 30 & 31 & 39 \\
\hline $\begin{array}{l}\text { Transport, storage } \\
\text { and } \\
\text { communication }\end{array}$ & $\begin{array}{l}\text { Medium- } \\
\text { high }\end{array}$ & 4 & 76 & 31 & 19 & 50 \\
\hline Construction & Medium & 9 & 103 & 38 & 26 & 36 \\
\hline $\begin{array}{l}\text { Financial and } \\
\text { insurance } \\
\text { services }\end{array}$ & Medium & 1 & 3 & 6 & 11 & 83 \\
\hline Mining and & & $<1$ & 3 & 28 & 14 & 58 \\
\hline
\end{tabular}




\begin{tabular}{|l|c|c|c|c|c|c|}
\hline quarrying & Medium & Low- \\
\hline $\begin{array}{l}\text { Agriculture, } \\
\text { forestry and } \\
\text { fishing }\end{array}$ & 19 & 470 & 55 & 30 & 15 \\
\hline $\begin{array}{l}\text { Human health and } \\
\text { social work } \\
\text { activities }\end{array}$ & Low & 2 & 11 & 7 & 14 & 81 \\
\hline Education & Low & 1 & 7 & 5 & 14 & 81 \\
\hline Utilities & Low & $<1$ & 3 & 10 & 13 & 77 \\
\hline $\begin{array}{l}\text { Public } \\
\text { administration } \\
\text { and defence; } \\
\text { compulsory social } \\
\text { security }\end{array}$ & Low & $<1$ & 0 & 2 & 8 & 90 \\
\hline
\end{tabular}

Note: Figures for employers and own-account workers are based on national household survey data from 114 countries representing $66 \%$ of global employment. Figures for firm size are based on national household survey data from 134 countries representing $78 \%$ of global employment. These are extrapolated to 2020 global employment by sector. Source: [11, p. 6-7].

3. Global working hours reduction is estimated by $10.5 \%$ : global working hours in the second quarter of 2020 are expected to be $10.5 \%$ lower than in the last pre-crisis quarter -4 quarters of 2019 . This is equivalent to 305 million full-time jobs (48 hours), which has significantly worsened the ILO's preliminary estimations of 195 million for the second quarter of 2020. This is mainly due to prolongation and extension of quarantine measures in the most countries around the world. This is true both to the countries with high and low economic development and income levels.

Thus, the situation on the labor market has worsened for all major regional groups. According to the ILO, the losses in working hours is $12.4 \%$ for American countries, for Europe and Central Asia - $11.8 \%$. According to expert estimates, the highest losses in working hours is expected for lower-income countries, and is about $12.5 \%$.

4. Among the most vulnerable groups in the labor market are informally employed workers (nearly 1.6 billion workers worldwide). Thus, according to the ILO estimates, the first month of the crisis has reduced the wages of this group by $60 \%$ all around the world. By region, the expected decline is largest in countries of Africa and Latin America, about $81 \%$. By income group, this indicator is $82 \%$ in low-income and low-middle-income countries, $28 \%$ in upper middle-income countries and $76 \%$ in high-income countries.

5. In addition, the relative poverty rate for informally employed workers (defined as the proportion of workers with a monthly wage below $50 \%$ of the average one) is expected to increase by almost $34 \%$ worldwide, i.e. $21 \%$ in the upper-middle-income countries income and $56 \%$ in countries with lower-middle-income countries [11]. Potential impact on the level of salaries of informally employed workers is presented in Table. 2. and in Fig. 2.

Table 2.

Potential impacts of the pandemic on earnings of informal workers

\begin{tabular}{|c|c|c|}
\hline Region & $\begin{array}{c}\text { Median earnings of informal } \\
\text { workers } \\
\text { pre COVID-19 (2016 PPP\$) }\end{array}$ & $\begin{array}{l}\text { Expected median earnings of } \\
\text { informal workers } \\
\text { in the first month of the crisis } \\
\text { (2016 PPP\$) }\end{array}$ \\
\hline Worldwide & 894 & 359 \\
\hline \multicolumn{3}{|c|}{ 1. By income group } \\
\hline 1.1. High-income countries & 1834 & 445 \\
\hline $\begin{array}{l}\text { 1.2. Upper-middle-income } \\
\text { countries }\end{array}$ & 497 & 359 \\
\hline $\begin{array}{l}\text { 1.3. Lower-middle and low-income } \\
\text { countries }\end{array}$ & 479 & 88 \\
\hline \multicolumn{3}{|c|}{ 2. By region } \\
\hline 2.1. Africa & 518 & 96 \\
\hline 2.2. Americas & 1298 & 244 \\
\hline 2.3. Asia and the Pacific & 549 & 430 \\
\hline 2.4. Europe and Central Asia & 1253 & 387 \\
\hline
\end{tabular}

Note: Estimates are based on weighted averages from 64 countries with data collected on a time interval between

2016 to 2019. Earnings include earnings from own-account workers, employers self-reported earnings and wages of wage employees. The estimates exclude unpaid family workers who are not usually asked to declare monetary earnings. Whenever possible, estimates include earnings from jobs other than the main job. The original local currency values have been converted to constant 2016 PPP dollars. The countries covered represent 65 per cent of the world's employees and include the economies with the largest population in each region. No data is available for Arab economies. 


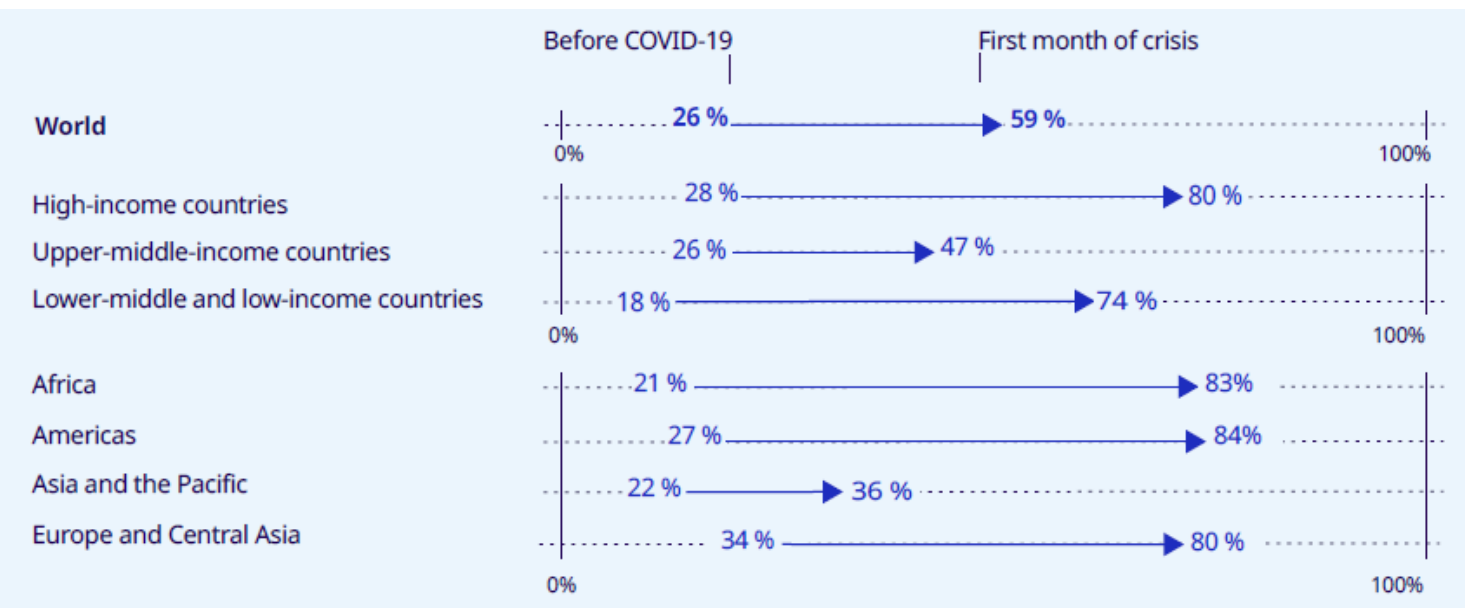

Fig. 2. Potential impacts of the pandemic on poverty levels of informal workers. Expected rise in relative poverty rates of informal workers

(Source: [11, p. 9])

The COVID-19 pandemic has a significant impact on the markets' development. Thus, there is a negative impact on the market of food and other necessities, which are now characterized by a high level of shortage of goods and a significant increase in prices for them. There is a decrease in the productive sector (engineering, electronics, etc.), as well as the non-productive sector (hotel, restaurant, beauty, etc.) due to the reduction of business activity.

Under the circumstances, economic shocks from the pandemic are also common foe the financial markets, including stock markets, market of bonds and commodities (including oil and gold). These events are compounded by a price conflict between the Russian Federation and Saudi Arabia, led to the collapse of oil prices and the collapse of stock markets in March, 2020. The United Nations Development Program (UNDP) expects \$ 220 billion in revenue cuts in developing countries.

However, the pandemic has a positive impact on some sectors of the global healthcare market. For example, the volume of the pharmaceutical market, markets of health commodities, medical equipment, and healthcare innovations, related to COVID-19, is going up today. Thus, it should be noted that the up-to-date world economy is characterized by a significant disproportion in the markets' development.

The analyze of the negative impact of COVID-19 on the global entrepreneurship, shows, that about 436 million entities in the riskiest sectors are now at high risk of work closures worldwide. More than $50 \%$ of them - about 232 million - are involved in the wholesale and retail trade. At the same time, employees who are on vacation on their own account, is about $45 \%$ of total employment rate in this sector. Small and medium-sized businesses are affected significantly.

The illustration of the indicative decrease in economic activity on the example of EU countries due to the reduction of economic and industrial activity is presented in fig. 3 .

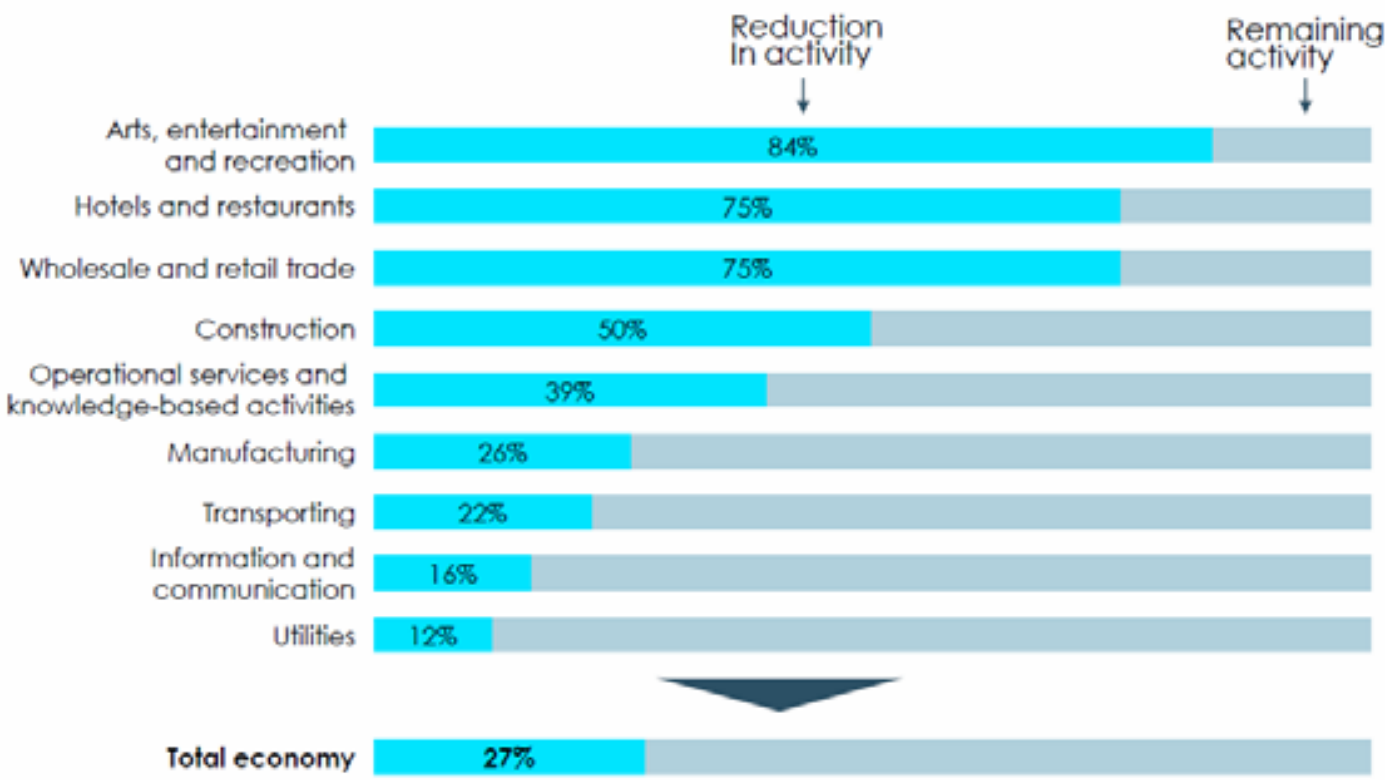

Fig. 3. Indicative current reduction in economic activity as a result of the lockdown in $E U$. Share of total Gross Value-Added (GVA)

(Source: [7, c. 4]) 
This negative impact is more clearly demonstrated by the day. In addition, the prolongation of quarantine and lock-down measures increases the risk of large-scale increases in government and corporate debts, creating major financial imbalances.

Experts argue that the crisis caused by the COVID-19 pandemic is unprecedented: it has led to the largest global recession in the economic history [10]. So, comparing it with the 2008 global financial crisis, we can identify the following major differences of the current crisis:

1) the economic shock of the current crisis caused disproportions in the different economic sectors. The annual output gap for the EU countries is illustrated at Fig. 4 and calculated by the following formula:

$$
\text { Annual output gap }(\%)=\frac{\text { Actwal } G D P-\text { Structwral } G D P}{\text { Structwral } G D P}
$$

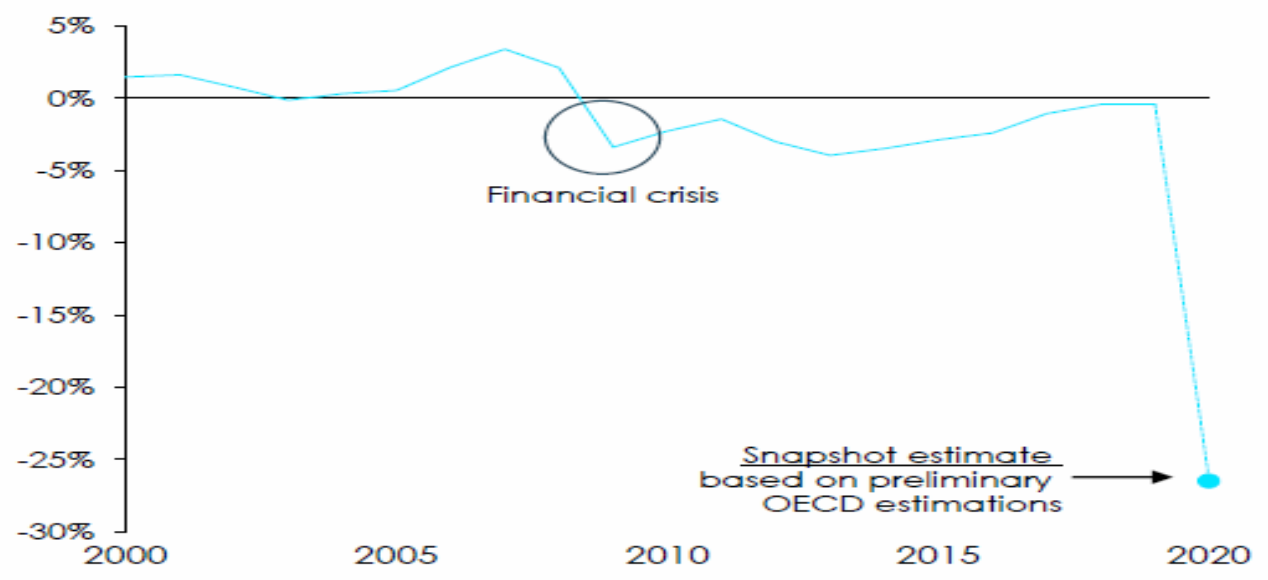

Fig. 4. Annual output gap for EU countries (Source: [7, p. 4])

2) The consequences of the current crisis are estimated 3-4 times more than the financial crisis of 2008. The potential consequences are illustrated by the example of the economy of the G7 countries (Fig. 5). The impact on annual GDP growth will depend on how long the quarantine measures will be.

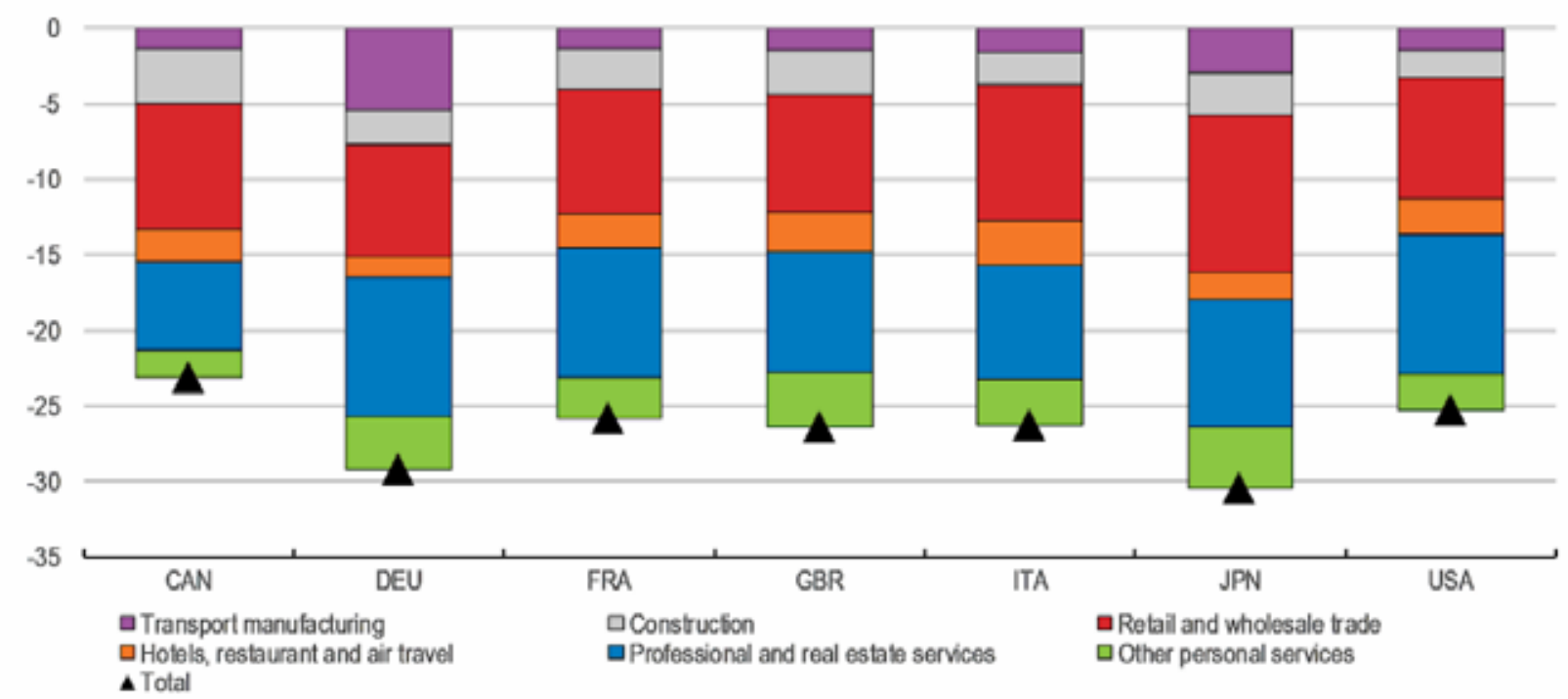

Fig. 5. The potential initial impact of partial or complete shutdowns on activity in the G7 economies. Per cent of GDP at constant prices

(Source: [5])

3) There is hope for a faster recovery than during the financial crisis. The European economies are in an entirely different economic landscape now, with much less need of fundamental financial rebalancing of the economy (e.g. less of a credit-fuelled housing and financial asset bubble). The average household debt to income ratio has decreased in many European countries (e.g. by $28 \%$ in Spain) since the last financial crisis, making households more resilient to interest rate spikes and periods of unemployment. Annual domestic credit growth in the European Union has been increasing in the last two years but is still approximately $10 \%$ lower than prior to the financial crisis. Growth in 
house prices has been moderate, and more in line with household income, unlike the rapid growth observed prior to the financial crisis. The capitalisation of the European banks has increased from on average of $7 \%$ risk-weighted assets in 2007 to $15 \%$ today $[7$, p. 4$]$;

4) Level of business activity in private sector has dropped by $20 \%$;

5) Quarantine measures negatively impacts on the markets' conjuncture, creating demand and supply shocks at the most of markets.

As a result, a prolonged quarantine measures and lockdown period increase the risk of a massive scaleup of governmental and corporate debt, building up fundamental financial imbalances that could prolong the recovery period.

This study does not analyze the impact on social, political, educational and other spheres of human activities, but we believe that in conditions of limited economic activity, they are also characterized by negative development indicators. UNDP estimates that not only economic, but also social and political crises can be expected in most countries of the world [4].

Most countries around the world have implemented national risk assessment scales and established crisis monitoring processes and systems. For example, Schlumberger has proposed a ranking of management risks by level, which is based on the assessment of geographical risk criteria, effective communication and crisis management and emergency (force majeure) processes. Criteria such as the availability and effectiveness of local health authorities to check for case confirmation or medical assistance, adherence to the recommendations of international health organizations (such as WHO), the effectiveness of healthcare providers, etc. could be also included. At the same time, the risk level of COVID-19 exposure in the country can be reduced based on the following criteria: reduction of infection rate, increase of recovery rate, improvement of per capita mortality rates, level of achievements in treatment or vaccination, etc.

Therefore, Schlumberger proposes to identify and implement certain restrictive actions at four levels that can help minimize health risks and adversely affect business activities, such as:

1) Schlumberger COVID-19 Level 0: for countries where no human COVID-19 case has been confirmed;

2) Schlumberger COVID-19 Level 1: for regions where fewer than 25 COVID-19 cases have been confirmed; confirmed;

3) Schlumberger COVID-19 Level 2: for a limited-impact country where 25 to 100 cases of COVID-19 are

4) Schlumberger COVID-19 Level 3: for countries that have suffered significantly in which more than 100 cases of COVID-19 have been confirmed [3, p. 3].

In [6], a long-term economic impact of the COVID-19 pandemic was assessed, based on the pace of the pandemic and the duration of the quarantine measures. Extensive quarantine measures are aimed at protecting the population most vulnerable to the SARS-CoV-2 virus and in order to reduce the overload on countries' healthcare systems.

So, on the base of these main goals, the duration of the quarantine depends on:

1) How quickly capacity to deal with severe cases can be built up (testing, recruitment, technology and treatment guidelines, etc.);

2) How quickly people are allowed to return to work and build immunity in large numbers. Thus, experts have identified three main scenarios:

I. Optimistic scenario: SARS-CoV-2 virus control measures are effective, the duration of the quarantine measures may be completed in the second quarter of 2020, enabling rapid economic and industrial recovery.

II. Intermediate scenario: SARS-CoV-2 virus control measures are moderately effective, with the economy locked out in the third quarter of 2020, when economic recovery may begin.

III. Severe scenario: SARS-CoV-2 virus control measures are less effective and take longer, which can lead to a second wave of pandemic, so unblocking economic and industrial activity may not take place before the effective vaccine is produced, around the beginning of 2021. Schematic scenarios are presented in Fig. 6.
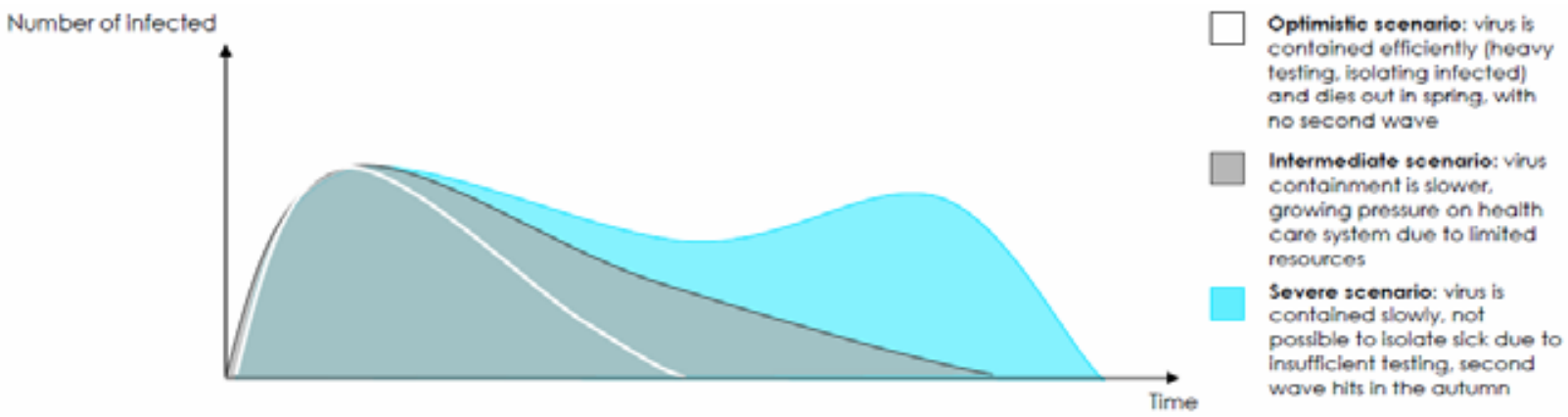

Fig. 6. Three scenarios for the development of the COVID-19 pandemic (Source: [7, p. 4]. 
Therefore, the key task for Governments is to identify ways to rebuild the business cycle as a whole for the economy. As it was noted earlier, the depth of the economic shock depends on the duration of the quarantine measures. Therefore, in [7] presents the economic recovery under three scenarios (Fig. 7).

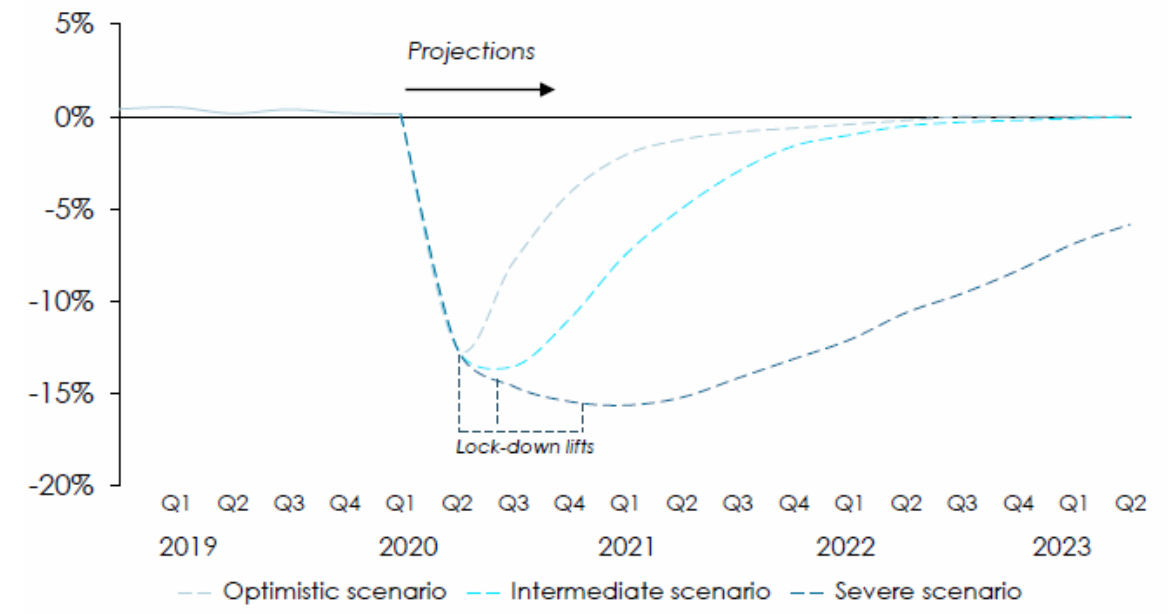

Fig. 7. Illustrative path of recovery in the three scenarios. Quarterly output gap (\% of long-run GDP) (Source: [7, p. 9].

Thus, key efforts by Governments, local authorities and companies of various forms of ownership should aim to minimize the negative impact caused by the COVID-19 pandemic on the bases of risk management. Risk management strategies based on crisis management should be developed for this to happen. Plans / programs for the minimization of losses from COVID-19 should be established and implemented, which requires addressing the following problems identified by WHO as prerequisites:

1) ensuring the implementation of an effective mechanism for preventing contamination by the SARS-CoV-2 virus (communication, distance, isolation and quarantine, limitation of transport, control and tracking of information on the disease development, testing);

2) providing sufficient infrastructure and manpower;

3) ensuring the effectiveness of medical care (planning and providing medical care, supporting the healthcare system so on);

4) providing financial support (financing, provision of guaranteed medical care and access of the population to medical care);

5) ensuring an effective management mechanism;

6) ensuring the implementation of an effective communication mechanism;

7) ensuring the implementation of an economic and management mechanism to minimize the effects of COVID-19 on the business activities of regions, countries and organizations;

8) application of crisis management tools;

9) continuous monitoring and analysis of the implementation of the above mechanisms in order to coordinate and regulate activities and develop forecasts and possible plans / programs for crisis management.

In general, the COVID-19 crisis program can be presented as follows:

I. Improving health care efficiency

1.1. Active anti-epidemiological policy against COVID-19

1.2. Establishment of an extensive national medical network identified as the basic one against COVID-19

1.3. Provide financial and logistical support to healthcare facilities

1.4. Strengthening health and safety measures for healthcare professionals

1.5. Incentives for medical personnel involved in the fight against COVID-19

II. Stimulating the economy and employment of the population

2.1. Active fiscal policy

2.2. Credit policy liberalization

2.3. Preferential lending and financial support to specific sectors of the economy, including health care

III. Supporting entrepreneurship, business and the labor market

3.1. Providing social protection for the country's population

3.2. Introducing measures to maintain employment level

3.3. Provide financial / tax and other business support

IV. Protecting employees in the workplace

4.1. Strengthening measures to ensure occupational safety and health

4.2. Ensuring flexible working conditions

4.3. Preventing discrimination and social exclusion

4.4. Ensuring equal access to health care 
4.5. Increased availability of paid holidays

V. Communication with the community

5.1. Strengthening the capacity of trade unions and professional associations

5.2. Strengthening the capacity of the authorities

5.3. Strengthening social dialogue, collective agreements and labor relations institutions.

The findings of the study and the prospects for further researches

In our opinion, the best and most effective way to maintain staff and population security globally, while maintaining business continuity and minimal disruption, is through ongoing cooperation between governments and large companies, based on effective communication. This needs the mutual exchange of information, coordinating treatment approaches and preventative measures, minimizing risks, planning and forecasting actions.

The main prospects for further researches in this field will be conducted regarding the currency of COVID-19 pandemic and evaluating its impact on the national and global economy.

\section{References.}

1. Bobylev, S. N. (2020), "Environmental consequences of COVID-19 on the global and Russian economics", Population and Economics, vol.4 (2), pp. 43-48.

2. World Health Organization (2020), "Coronavirus (COVID-19)", available at: https://covid19.who.int/ (accessed 30 April 2020).

3. Schlumberger (2020), “COVID-19 Crisis Management Plan”, available at: https://www.slb.com/who-we-are/hse/covid-19 (accessed 30 April 2020)

4. United Nations Development (2020), "Programme COVID-19 pandemic. Humanity needs leadership and solidarity to defeat the coronavirus", available at: https://www.undp.org/content/undp/en/home/covid-19-pandemicresponse.html (accessed 30 April 2020).

5. OECD (2020), "Evaluating the initial impact of COVID-19 containment measures on economic activity", available at: https://www.oecd.org/coronavirus/policy-responses/evaluating-the-initial-impact-of-covid-19containment-measures-on-economic-activity/ (accessed 30 April 2020).

6. Næss-Schmidt, H. S. Jensen, J. B. Christiansen, B. B. Virtanen, L. and Nielsen, A. L. (2020), "COVID-19 Exit strategies. Learnings from three Scandinavian countries", available at: https:/www.copenhageneconomics.com/publications/publication/covid-19-exit-strategies (accessed 30 April 2020).

7. Næss-Schmidt, H. S. Jensen, J. B. Christiansen, B. B. and Virtanen, L. (2020), "Economic consequences of the COVID-19 pandemic", Copenhagen Economics, available at: https:/www.copenhageneconomics.com/publications/publication/economic-consequences-of-the-covid-19-pandemic (accessed 30 April 2020).

8. International Labour Organization (2020), "ILO Monitor: COVID-19 and the world of work. Third edition Updated estimates and analysis", available at: https://www.ilo.org/wcmsp5/groups/public/---dgreports/--dcomm/documents/briefingnote/wcms_743146.pdf (accessed 30 April 2020).

9. Mazneva, D. V. (2020), "The impact of COVID-19 on the airline industry", Science and innovations in XXI century: Current issues, discoveries and achievements, pp. 82-87.

10. Kaplan, J. Frias, L. and McFall-Johnsen, M. (2020), "A third of the global population is on coronavirus lockdown - here's our constantly updated list of countries and restrictions", Business Insider Australia, available at: https://www.businessinsider.com.au/countries-on-lockdown-coronavirus-italy-2020-3 (accessed 30 April 2020).

11. Romei, V. and Burn-Murdoch, J. (2020), "Real-time data show virus hit to global economic activity", Financial times, available at: https://www.ft.com/content/d184fa0a-6904-11ea-800d-da70cff6e4d3 (accessed 30 April 2020).

12. World Health Organization (2020), "WHO Director-General's opening remarks at the media briefing on COVID-19. 3 March 2020", available at: https://www.who.int/dg/speeches/detail/who-director-general-s-openingremarks-at-the-media-briefing-on-covid-19---3-march-2020 (accessed 30 April 2020).

Bibliography.

1. Bobylev S. N. Environmental consequences of COVID-19 on the global and Russian economics. Population and Economics. 2020. Vol. 4 (2). Pp. 43-48. Doi: https://doi.org/10.3897/popecon.4.e53279

https:/covid19.who.int/
3. COVID-19 Crisis Management Plan. Schlumberger. 2020. Retrieved from: https://www.slb.com/whowe-are/hse/covid-19

4. COVID-19 pandemic. Humanity needs leadership and solidarity to defeat the coronavirus. United Nations Development Programme $\quad$ web-site. $2020 . \quad$ Retrieved from: https://www.undp.org/content/undp/en/home/covid-19-pandemic-response.html

5. Evaluating the initial impact of COVID-19 containment measures on economic activity. OECD : web-site. 2020. Retrieved from: https:/www.oecd.org/coronavirus/policy-responses/evaluating-the-initial-impact-ofcovid-19-containment-measures-on-economic-activity/ 
6. Helge Sigurd Næss-Schmidt, Jonas Bjarke Jensen, Benjamin Barner Christiansen, Laura Virtanen, Astrid Leth Nielsen. COVID-19 Exit strategies. Learnings from three Scandinavian countries. April 2020. Retrieved from: https://www.copenhageneconomics.com/publications/publication/covid-19-exit-strategies

7. Helge Sigurd Næss-Schmidt, Jonas Bjarke Jensen, Benjamin Barner Christiansen, Laura Virtanen. Economic consequences of the COVID-19 pandemic. March, 2020. Copenhagen Economics. 12 p. Retrieved from: ttps://www.copenhageneconomics.com/publications/publication/economic-consequences-of-the-covid-19-pandemic

8. ILO Monitor: COVID-19 and the world of work. Third edition Updated estimates and analysis. International Labour Organization, 2020. 23 p. Retrieved from: https://www.ilo.org/wcmsp5/groups/public/--dgreports/---dcomm/documents/briefingnote/wcms_743146.pdf

9. Mazneva D. V. The impact of COVID-19 on the airline industry. Наука и инновации в XXI веке: Актуальные вопросы, открытия и достижения. 2020. С. 82-87

10. McFall-Johnsen, Juliana Kaplan, Lauren Frias, Morgan. A third of the global population is on coronavirus lockdown - here's our constantly updated list of countries and restrictions. Business Insider Australia : web-site. Retrieved from: https://www.businessinsider.com.au/countries-on-lockdown-coronavirus-italy-2020-3

11. Real-time data show virus hit to global economic activity. 22 March 2020. Retrieved from: www.ft.com

12. WHO Director-General's opening remarks at the media briefing on COVID-19. 3 March 2020. World Health Organization : web-site. Retrieved from: https://www.who.int/dg/speeches/detail/who-director-general-sopening-remarks-at-the-media-briefing-on-covid-19---3-march-2020

Стаття надійшла до редакиії 04.05.2020 p. 